\title{
ע Työhön paluu ja työkyvyttömyyseläkkeen riski sairauspoissaolon jälkeen. Katsaus 2008-2019 julkaistuun suomalaistutkimukseen.
}

Suomessa on tehty paljon sairauspoissaoloihin ja työkyvyttömyyteen liittyvää tutkimusta. Tutkimuksen tekemistä puoltaa sairauspäivärahakausien ja työkyvyttömyyseläkkeiden suuri yhteiskunnallinen merkitys ja hyvät rekisteriaineistomme. Kansainvälisten tutkimusten tulosten suora soveltaminen ei aina tule kyseeseen johtuen maiden erilaisista lainsäädännöistä ja vakuutusjärjestelmistä, mikä korostaa kotimaisen tutkimuksen tärkeyttä päätöksenteon pohjaksi. Suomessa on toteutettu useita lainsäädännöllisiä sairauspäivärahakausia koskevia muutoksia, joilla tavoitellaan työhön paluun helpottamista ja työkyvyttömyyseläkkeelle siirtymisen vähenemistä. Työkyvyttömyysetuisuuksiin liittyvä tutkimus on tarpeen, koska sosiaaliturvajärjestelmäämme kohdistuu muutospaineita. Tässä katsausartikkelissa käsitellään vuonna 2008 ja sen jälkeen julkaistuja suomalaisia sairauspoissaolotutkimuksia, jotka liittyvät työhön paluuseen ja työkyvyttömyyseläkkeen riskiin. Katsaukseen valittiin 29 julkaisua, joista useat pohjautuivat rekisteriaineistoihin. Työhön paluuta sairauspoissaolon jälkeen on selvitetty erityisesti tuki- ja liikuntaelinsairauksien ja mielenterveyden häiriöiden yhteydessä. Molempien diagnoosiryhmien osalta osasairauspäivärahan käyttö näyttää vaikuttavan myönteisesti työhön paluuseen. Työhön paluu ei kuitenkaan ole riippuvainen ainoastaan sairaudesta, yksilöstä tai terveyteen liittyvistä seikoista, sillä myös elin- ja työskentelyolosuhteet sekä kulttuuriset ja organisaatioon liittyvät tekijät ovat keskeisiä. Työkyvyttömyyseläkkeelle voidaan päätyä hyvin erilaisen sairauspoissaolohistorian kautta. Työkyvyttömyyseläkkeen diagnoosilla ja ammattiryhmällä voidaan selittää osa kehityspolkujen eroista. Osasairauspäiväraha vähentää täyden työkyvyttömyyseläkkeen riskiä, mutta lisää osaaikaisen työkyvyttömyyseläkkeen riskiä. Hyödyllistä olisi jatkaa osasairauspäivärahan vaikutusten selvittämistä, sillä sen käyttö on yleistynyt hitaasti ja sukupuolten välillä on suuri ero etuisuuden käytössä. Lisäksi tarpeellista on tieto tehokkaista kuntoutustoimenpiteistä, jotka edesauttavat työhön palaamista. Huomiota tulisi myös suunnata työttömien työkyvyttömyyden pitkittymisen estämiseen, sillä työttömät ovat työterveyshuollon palvelujen ulkopuolella.

ASIASANAT: sairauspoissaolo, sairauspäiväraha, sairausloma, työhön paluu, työkyvyttömyyseläke

KAARINA REINI 


\section{YDINASIAT}

- Suomessa on tehty runsaasti sairauspoissaoloja ja työkyvyttömyyttä koskevia tutkimuksia, joista iso osa nojautuu kattaviin rekisteriaineistoihin.

- Viimeaikaiset lakimuutokset Kelan maksamaan sairauspäivärahaan näyttävät tukevan työhön osallistumisastetta.

\section{JOHDANTO}

Sairauspäivärahakausiin ja sairauspoissaoloihin liittyvää tutkimusta on tehty Suomessa paljon. Erilaisia tutkimuksellisia näkökulmia on ollut varsin runsaasti, koska sairauspoissaoloihin ovat yhteydessä sairauden ohella ainakin vakuutusjärjestelmä (sairausetuusjärjestelmä ja vaihtoehtoiset etuudet), yhteiskunnan taloudellinen tilanne ja työmarkkinat, fyysiset ja psykososiaaliset työskentelyolosuhteet, perhetilanne, terveyskäyttäytyminen ja elämäntyyli, sosioekonominen tilanne sekä sukupuoli ja ikä (1). Tutkimusta ovat helpottaneet kattavat rekisteriaineistot ja jo pelkästään Kelan korvaamien sairauspäivärahakausien suuri yhteiskunnallinen merkitys puoltaa analyysien tekemistä. Vuonna 2017 Kela maksoi sairauspäivärahoja 800 miljoonaa euroa (2), joista mielenterveysperusteisia sairauspäivärahoja maksettiin 210 miljoonaa euroa ja tuki- ja liikuntaelinsairausperusteisia 260 miljoonaa euroa.

Sairauspoissaolojen yleisyyttä ja kestoa vähentävillä toimenpiteillä on merkittävä taloudellinen vaikutus yhteiskunnalle $(3,4)$. Suomessa on 2000-luvun aikana tehty useita sairauspäivärahakausia koskevia lainsäädännöllisiä uudistuksia, joiden tavoite on nopeuttaa ja helpottaa työhön paluuta sairauspoissaolon jälkeen. Nämä muutokset ovat sairauspäivärahajärjestelmän täydentyminen osasairauspäivärahalla vuonna 2007 sekä vuonna 2012 voimaan tulleet työnantajan ilmoitusvelvollisuus työterveyshuoltoon yli 30 päivää kestävistä sairauspoissaoloista ja Kelan korvauksen hakeminen kahden kuukauden kuluessa työkyvyttömyyden alkamisesta sekä työterveyshuollon lausuntovelvollisuus yli kolme kuukautta kestävissä sairauspoissaoloissa. Vuoden 2012 lakimuutoksista käytetään myös nimitystä 30-60-90-sääntö (5). Erittäin kattava kuvaus sairausvakuutusetuuksien ml. sairauspäivärahaa koskevasta lainsäädännöllisestä kehi-
- Työterveyshuolto on keskeinen toimija pitkittyvän työkyvyttömyyden ehkäisemisessä.

- Lisätutkimusta tarvitaan osasairauspäivärahan vaikutuksista ja vaikuttavista kuntoutustoimenpiteistä. tyksestä löytyy Kelan tilastollisesta vuosikirjasta (2).

Suomessa sairauspoissaolot koostuvat lyhyistä omaan ilmoitukseen perustuvista sairauspoissaoloista ja lääkärin toteamista työkyvyttömyysjaksoista. Kelan maksamaa sairauspäivärahaa varten tarvitaan aina lääkärintodistus ja sitä maksetaan omavastuuajan jälkeen. Omavastuuaika on sairastumispäivä ja sitä seuraavat 9 arkipäivää. Sairauspäivärahaa voivat saada 16-67vuotiaat ja etuutta maksetaan enintään 300 arkipäivältä eli noin vuoden ajan. Mikäli työkyvyttömyys jatkuu tätä pidempään, se voi johtaa työkyvyttömyyseläkkeen hakemiseen.

Työikäisten kaikista sairauspoissaoloista ei ole olemassa kattavaa pitkää aikasarjaa Suomessa, sillä lyhyistä sairauspoissaoloista ei kerätä tietoa kansallisiin rekistereihin. Lyhyiden sairauspoissaolojen merkityksestä ja seuraamuksista on saatu tietoa Helsingin kaupungin työntekijöiden aineiston (6) sekä kuntasektorin henkilöstön seurantatutkimuksen avulla $(7,8)$. Lisäksi yksi mahdollisuus saada tietoa lyhyistä sairauspoissaoloista ovat työterveyshuollon pitämät rekisterit. Työterveyshuollosta saatavien tietojen ongelmana on kuitenkin seurannan kattavuus, koska työterveyshuollon palvelut ovat sidoksissa työsuhteeseen. Lyhyiden sairauspoissaolojen kohdalla tutkimustulosten yleistettävyys koko työikäiseen väestöön on rajoitetumpaa kuin Kelan sairauspäiväraha-aineistoon perustuvien tulosten.

Suomessa työkyvyttömyyseläkettä maksetaan kansaneläkejärjestelmästä, työeläkejärjestelmästä tai molemmista. Työkyvyttömyyseläke voi olla toistaiseksi myönnetty tai määräaikainen kuntoutustuki eli määräaikainen työkyvyttömyyseläke. Työeläkejärjestelmän puitteissa voidaan maksaa myös osatyökyvyttömyyseläkettä tai osakuntoutustukea. Osatyökyvyttömyyseläkkeet ovat yleistyneet 2010-luvulla, mutta verrattaessa 
täyden työkyvyttömyyseläkkeen saajiin määrä on vielä pieni. Vain noin 17 prosenttia kaikista työkyvyttömyyseläkkeistä oli osaeläkkeitä vuoden 2018 lopussa (9). Yhteensä työkyvyttömyyseläkkeellä oli 199000 henkilöä vuoden 2018 lopussa (10). Täyttä työkyvyttömyyseläkettä saavilla yleisin syy työkyvyttömyyteen on mielenterveyden häiriöt ja osaeläkkeen yleisin syy on tuki- ja liikuntaelinsairaudet (11). Työkyvyttömyyseläkettä kansaneläkejärjestelmästä saaville tyypillistä on matala koulutustaso ja nuorena alkanut työkyvyttömyys. Työeläkejärjestelmän työkyvyttömyyseläkkeen saajilla on pitempi koulutus ja työura, useimmiten työkyvyttömyyseläkkeelle oli siirrytty vasta 50 ikävuoden jälkeen (12). Polut työkyvyttömyyseläkkeelle voivat olla erilaisia. Blomgrenin ja työtovereiden raportin (13) mukaan vuonna 2004 noin neljännes siirtyi työkyvyttömyyseläkkeelle 300 päivän sairauspäivärahakauden ohittaen. Lisäksi työttömyyden on havaittu olevan yleisempää niiden joukossa, jotka siirtyvät työkyvyttömyyseläkkeelle muuta kuin sairauspäivärahakauden kautta (14).

Tässä katsausartikkelissa tarkastellaan suomalaisilla aineistoilla tehtyjä sairauspäivärahakausiin tai sairauspoissaoloihin liittyviä tutkimuksia, jotka on julkaistu vuonna 2008 tai sen jälkeen. Aihetta on lisäksi rajattu koskemaan sairauspoissaolojen jälkeistä työhön paluuta ja työkyvyttömyyseläkettä. Lisäulottuvuutta tarkasteluun tuovat useat 2000-luvulla tehdyt sairauspäivärahaa koskevat lakimuutosten vaikutukset. Sairauspäiväraha ja pidemmät sairauspoissaolot ovat vahvasti sidoksissa lainsäädäntöön, mistä syystä muista maista saatujen sairauspoissaolotutkimusten tulosten suora soveltaminen on rajoitettua. Sama koskee myös työkyvyttömyyseläkkeitä. Myöntämisehtojen ohella maiden välisiin eroihin työkyvyttömyyseläkkeissä vaikuttaa myös se, mitä muita reittejä varhaiseen työstä poistumiseen on tarjolla.

\section{AINEISTON VALINTA}

Kirjallisuushaut toteutettiin toukokuun 2019 aikana. Artikkeleita haettiin PubMed-tietokannasta sekä kotimaisesta artikkelitietokannasta ARTO. PubMed-hauissa hakusanoina käytettiin sickness absence, sickness allowance, sick leave, part-time sickness absence, part-time sickness allowance, part-time sick leave yhdistettyinä erilai- siin kombinaatioihin hakusanojen return to work, re-employment, disability pension ja disability retirement kanssa. Jokaiseen hakuun oli myös yhdistetty hakusana Finland. Kirjallisuushaut rajattiin lisäksi koskemaan artikkeleita, jotka oli julkaistu vuonna 2008 tai sen jälkeen. Eniten viitteitä löytyi hakusanayhdistelmällä sickness absence ja disability pension ja Finland $(n=41)$. ARTO-tietokannasta kirjallisuutta haettiin hakusanoilla sairausloma, sairauspäiväraha ja sairauspoissaolo sekä yhdistämällä näihin hakusanoihin työhön paluu ja työkyvyttömyyseläke. Eniten lähteitä löytyi hakusanalla sairausloma $(n=128)$. Yhteensä PubMed- ja ARTO-tietokantahauissa viitteitä löytyi 221, kun duplikaatit oli poistettu. Hakuja täydennettiin tekemällä edellä mainituilla hakusanoilla Google- ja Google Scholar -hakuja. Lisäksi yksi artikkeli poimittiin mukaan kirjallisuushakujen kautta löydetyn artikkelin viitelistasta ja yksi artikkeli otettiin mukaan vertaisarvioijan suosituksen perusteella. Kuviossa 1 on esitettynä kirjallisuuden valinta hakuprosessin lisäksi.

Tähän katsaukseen valittiin kirjallisuushakujen perusteella 29 julkaisua, jotka on kuvattu yksityiskohtaisemmin taulukossa 1 . Valintakriteerinä oli, että tutkimuksessa oli hyödynnetty suomalaisia aineistoja ja että tutkimuksen kohde liittyi sairauspoissaolon jälkeiseen työhön paluuseen tai työkyvyttömyyden riskiin tai sairauspäivärahaa koskevien lainsäädännöllisten vaikutusten selvittämiseen. Monessa katsaukseen valitussa tutkimuksessa on hyödynnetty erilaisia rekisteritietoja, kuten Kelan sairauspäivärahakausitietoja ja Eläketurvakeskuksen (ETK) aineistoja työkyvyttömyyseläkkeistä. Useissa artikkeleissa tutkimuksen otos on muodostettu Työterveyslaitoksen Kuntasektorin henkilöstön seurantatutkimuksesta (Finnish Public Sector Study, FPS) (15), joka koostuu Kunta10-tutkimuksesta (Helsinki, Espoo, Vantaa, Turku, Tampere, Oulu, Raisio, Naantali, Nokia, Valkeakoski ja Virrat) sekä 21 sairaalan työntekijöiden tiedoista. Tämän tutkimusaineiston osalta on huomioitava, että aineistossa naiset ovat yliedustettuina miehiin verrattuna. Kuntasektorin henkilöstön seurantatutkimuksen tavoite on selvittää kunta-alan henkilöstön työelämän ja terveyden muutoksia. 
Taulukko 1. Tiivistelmä katsaukseen valituista julkaisuista.

\begin{tabular}{|c|c|}
\hline Kirjoittaja $(t)$ & $\begin{array}{l}\text { Tutkimuksen kohde, } \\
\text { otos }\end{array}$ \\
\hline $\begin{array}{l}\text { Viikari- } \\
\text { Juntura E, } \\
\text { ym. (4) }\end{array}$ & $\begin{array}{l}\text { Tutkimukseen valittiin } \\
\text { mielenterveyssyistä tai } \\
\text { tuki- ja liikuntaelin- } \\
\text { sairauden perusteella } \\
\text { osa- tai kokoaikaista } \\
\text { sairauspäivärahaa vuosi- } \\
\text { na } 2010-2011 \text { saaneet. } \\
\text { Vastaavuuspistemääriin } \\
\text { perustuvaa kaltaistus- } \\
\text { ta (propensity score } \\
\text { approach) hyödynnettiin } \\
\text { kontrolli- ja tapausryh- } \\
\text { män vertailuissa (yhteen- } \\
\text { sä } n=2 \times 1878 \text { ) }\end{array}$ \\
\hline
\end{tabular}

Viikari- Tutkimukseen otettiin

Juntura E, kaksi $70 \%$ satunnai-

ym. (5) sotosta $31.12 .2010 \mathrm{ja}$

31.12.2013 18-58-vuotiaista henkilöistä.

Otoksia rajattiin vielä keskittymällä analysoimaan henkilöitä, joilla oli työ- ja sairaushistoriaa $(\mathrm{n}($ otos 1$)=17529 \mathrm{ja}$ $\mathrm{n}($ otos 2$)=15166)$.

Sumanen H, Tutkimusaineisto on osa ym. (6) Helsinki Health Study -aineistoa. Helsingin kaupungin työntekijöistä tutkimukseen valittiin 20-49-vuotiaita (n=6790) (vuosi 2004).

Laaksonen Tutkimusaineistoon poiM, ym. (14) mittiin kaikki 30 vuotta täyttäneet, joiden työ- tai kansaneläkejärjestelmän mukainen työkyvyttömyyseläke alkoi vuoden 2011 aikana $(\mathrm{n}=21430)$.
Tavoite

Päätulokset

Analysoida sosiaaliturva- Osasairauspäivärahaa kustannusten eroja osaja kokosairauspäivärahaa saaneiden välillä.

Tutkia vuoden 2012 saaneiden sosiaaliturvakustannukset olivat $2395 €$ pienemmät kuin täyttä sairauspäivärahaa saaneilla. Suurimmat säästöt kertyivät eroista kuntoutuksessa ja eläköitymisessä.

sairausvakuutuslain ja työterveyshuoltolain muutoksen vaikutuksia työhön paluuseen sekä etuisuuksien käyttöön.

Tutkia kuinka aiemmat lyhyet sairauspoissaolot ovat sidoksissa myöhempiin pitempiin sairauspoissaoloihin mielenterveyssyistä.

Tarkastella työkyvyttömyyseläkkeelle jääneiden sairauspäiväraha-, kuntoutus- ja työttömyyshistoriaa. eläkkeelle jääneiden sai-
Lakimuutoksilla ei näyttänyt olevan vaikutusta pian lain voimaantulon jälkeen pitkittyneellä sairauspäivärahakaudella olleiden työhön paluuseen tai työhön osallistumisen edistämiseen.

Mielenterveyssyistä pidetyn pitkän sairauspoissaolon riski kasvoi, mikäli lyhyitä poissaolokausia tai sairauspäiviä oli paljon: kolme sairauspoissaolojaksoa tai 8 päivää lyhyitä sairauspoissaoloja vuodessa merkitsi korkeaa riskiä.

Täydelle työkyvyttömyysrauspoissaolot lisääntyivät työkyvyttömyyseläkkeen lähestyessä, mutta isolla joukolla työkyvyttömyyseläkkeelle jääneistä ei ollut takanaan huomattavaa sairauspäivärahahistoriaa. Osasyynä tähän on työttömyystaustan yleisyys työkyvyttömyyseläkkeelle jääneiden joukossa. Kuntoutukseen osallistuminen ei ollut merkittävää ja se yleistyi vasta viimeisten työkyvyttömyyseläkkeelle jäämistä edeltäneiden vuosien aikana. Osatyökyvyttömyyseläkkeelle jääneillä oli selvästi enemmän sairauspäivärahoja ja vähemmän työttömyyttä ja he osallistuivat enemmän kuntoutukseen kuin täydelle työkyvyttömyyseläkkeelle jääneet.
Aineistolähteet Aineisto Haku

vuosilta

Kelan ja ETK:n 2010- Google

rekisteriaineistot. $2013 \quad$ Scholar

Kelan ja ETK:n 2009-

ARTO

rekisteriaineistot 2014

Työnantajan eli

2004-

PubMed

Helsingin kaupun-

gin rekisteritiedot

sairauspoissaolois-

ta ja Kelan rekiste-

ritiedot sairauspäi-

värahakausista.

ETK:n ja Kelan

2001rekistereistä koottu 2011

aineisto 
Ervasti J, Katsausartikkeli, jossa ym (16) tehdään myös analyysi suomalaiselle Kuntasektorin henkilöstön seurantatutkimusaineistolle (Finnish Public Sector study, FPS). Aineisto koostuu 10 kunnan ja 21 sairaalan työntekijöistä. Tässä tutkimuksessa rajattiin aineistoa koskemaan vain niitä, joilla masennukseen liittyvä sairauspoissaolo $(\mathrm{n}=5572)$

Ervasti J, Kuntasektorin henkiym. (17) löstön seurantatutkimuksen aineisto (FPS). Tutkimukseen valittiin henkilöt, joilla oli mielenterveysperustainen poissaolo seuranta-ajalla 2005-2011 ( $\mathrm{n}=9908)$.
Selvittää työhön paluuta ennustavia tekijöitä aineistolla, joka koostui työntekijöistä, joilla masennuksesta johtuva poissaolo.

Tutkia miten yhteisnen tai somaattinen, vaikuttaa masennuksen yhteydessä työhön paluuseen. sairastavuus, psyykki-
Nopeampaan työhön paluuseen masennuksen jälkeen yhdistyivät korkea koulutus ja parempi kotrolli työtehtävistä. Työn kuormittavuus ja määräaikainen työsuhde yhdistyivät hitaampaan työhön paluuseen.
Kuntasektorin rantatutkimuksen aineisto (FPS).
Yhteissairastavuus, sekä psyykkinen että somaattinen, masennuksen kanssa vähensi työhön paluun todennäköisyyttä, kun vertailu tehtiin ainoastaan masennusta sairastaviin.
MattilaHolappa P, ym. (18)
Kuntasektorin henkilöstön seurantatutkimuksen aineisto (FPS). Tutkimukseen valittiin henkilöt, jotka olivat työssä vuoden 2004 aikana ja joilla oli ainakin yksi mielenterveysperustainen poissaolo seuranta-ajalla 2005-2011 ( $\mathrm{n}=10496)$.
Tutkia työhön paluuta sekä työkyvyttömyysjaksojen uusiutumista ennustavia tekijöitä ikäryhmittäin, kun taustalla on mielenterveyden häiriö.
Nuoremmissa ikäryhmissä (21-50-vuotiaat) työhön paluu oli todennäköisempää kuin yli 50-vuotiailla. Työkyvyttömyysjakson uusiutuminen oli todennäköisempää yli 50-vuotiailla ja 35-50-vuotiailla verrattuna nuorempaan ikäryhmään. Masennusta sairastavat ikääntyneet työntekijät palasivat vähiten takaisin työhön. Matala koulutus yhdistyi toistuvaan työkyvyttömyysjakson riskiin 50-vuotiailla ja nuoremmilla.

Masennuksen osalta keskimääräinen sairauspoissaolon pituus oli 38 päivää naisille ja 46 päivää miehille ennen pysyvää työhön paluuta. Vastaavasti ahdistushäiriöiden kohdalla sairauspoissaolon pituus oli 22-24 päivää. Tuki- ja sairauspoissaolon pituus oli 21-42 päivää ennen pysyvää työhön paluuta. Korkea ikä, terveysongelman vaikeus sekä yhteissairastavuus ennustivat pitempää poissaoloa ennen pysyvää työhön paluuta. liikuntaelinsairauksissa
Työnantajien rekisteritiedot; rekisteritiedot sairauspäivärahakausista, korvatuista lääkeostoista, lääkkeiden erityiskorvausoikeuksista, sairaalasta kotiutumisesta ja pahanlaatuisista kasvaimista. Lisäksi ETK:n rekisteriaineistoja työkyvyttömyyseläkkeistä.

Työnantajien, Kelan, ETK:n ja Tilastokeskuksen rekisteritiedot.

\section{5- Artik- \\ 2011 kelin viitelis- tasta}

2004- Google 2011 Scholar

2005- PubMed

Kelan rekisteri2011 päivärahakausista. Lisäksi rekisteriaineisto korvatuista lääkeostoista, oikeudesta erityiskorvattuihin lääkkeisiin ja sairaalasta kotiutumisesta. 
Kausto J, Kuntasektorin henkiym. (20) löstön seurantatutkimuksen aineisto (FPS).

Tutkimukseen poimittiin 123506 henkilöä, jotka olivat työelämässä 1.1.2005. Joukkoa rajattiin siten, että analyyseihin otettiin mukaan tutkittavat, joilla oli v. 2005-2011 vähintään yksi yli 10 arkipäivää kestänyt sairauspoissaolojakso tai rannekanavaleikkaushoitojakso $(\mathrm{n}=35120)$.
Viikari-

Satunnaistettu

Juntura E, kontrolloitu koe, ym. (21) jossa tutkittavat olivat 18-60-vuotiaita ja joilla oli tuki- ja liikuntaelinsairaus $(n=63)$.
Tuottaa tietoa sairauspoissaolojen kestosta, uusiutumisesta ja pysyvään työhön paluuseen kuluneesta ajasta sairauspoissaolojen kannalta keskeisissä sairausryhmissä kuntatyöntekijöillä.

Selvittää tuki- ja

liikuntaelin sairauksia sairastavien osa-aikaisen sairauspäivärahan vaikutuksia työhön paluuseen ja sairauspoissaoloihin.
Selkäsärystä johtuneet sairauspoissaolot päättyivät onnistuneeseen työhön

paluuseen noin kolmessa viikossa. Selän nikamavälilevyjen sairauksissa aikaa kului keskimäärin kuusi viikkoa. Polven nivelrikosta aiheutuneet sairauspoissaolot päättyivät onnistuneeseen työhön paluuseen keskimäärin kuukauden kuluessa. Vastaavasti lonkan nivelrikossa aika oli runsaat 2,5 kuukautta. Rannekanavaleikkauksen jälkeen työhön paluuseen kului keskimäärin 5 viikkoa. Masennuksesta johtuvan sairauspoissaolon jälkeen onnistunut työhön paluu tapahtui noin 6 viikossa. tapahtui nopeammin

Selvittaa osasairauspäivärahaa koskevan lainsäädäntöuudistuksen vaikutuksia työhön osallistumiseen henkilöillä, joilla on pitkiä sairauspoissaoloja.
Kyselyaineistot

yhdistettyinä

kansallisiin ja työnantajien rekisteriaineistoihin.
Pysyvä työhön paluu osa-aikaisella kuin kokoaikaisella sairauspäivärahalla olleille. Yhteenlaskettuja sairauspäiviä oli myös vuodessa noin $20 \%$ vähemmän kuin kokoaikaisella sairauspäivärahakaudella olleilla.

Osa-aikainen sairauspoissaolo ei lisännyt kipuun liittyviä oireita eikä vähentänyt toimintakykyä. Vaikutukset olivat myönteiset itsearvioituun terveyteen ja terveyteen liittyvään elämänlaatuun.

Osasairauspäiväraha nosti työhön osallistumista.

\section{Kyselyaineisto. \\ 2006 2010}

Kyselyaineisto.

ilmoi-

tettu
PubMed

PubMed

vaikutukse näkyivät 45-54- ja

55-65-vuotiailla ja heillä, joilla poissaolo johtui mielenterveyden häiriöistä. Kun analyyseissa vertailtavat ryhmät tehtiin enemmän samankaltaisiksi, näkyi osasairauspäivärahan myönteinen vaikutus kaikissa ikäryhmissä ja lähes kaikissa sairausryhmissä paitsi ei vammoissa
Kelan ja ETK:n 2007- Google rekisteriaineistot. $2008 \quad$ Scholar 
ViikariJuntura E, mielenterveyssyistä tai ym. (24) tuki- ja liikuntaelinsairauden perusteella osa- tai kokoaikaista sairauspäivärahaa vuosina 2010-2011 saaneet.

Vastaavuuspistemääriin perustuvaa kaltaistusta (propensity score approach) hyödynnettiin kontrolli- ja tapausryhmän vertailuissa (yhteensä $\mathrm{n}=2 \times 1878$ )

Halonen JI, Kuntasektorin henkilösym. (25) tön seurantatutkimuksen aineisto (FPS): $\mathrm{n}=72164$ julkisen sektorin työntekijää, joilla jatkuva

Halonen JI, $\quad 70 \%$ otos Suomessa ym. (26) asuvasta työikäisestä väestöstä sekä vuonna 2010 että 2013. työsuhde. voimaan tulleiden pitkittyneitä sairauspoissaoloja koskevien lakimuutosten vaikutukset työhön paluuseen ja työhön osallistumiseen.

Tutkia vaikuttiko lakimuutos työnantajien ilmoitusvelvollisuudesta pitkittyneistä sairauspoissaoloista työhön paluuseen ja työhön osallistumiseen.

Tutkia työhön paluuta masennuksen jälkeen ja vertailla löytyykö eroja työsuhteen perusteella. mukseen valittiin henkilöt, jotka olivat seuran2005) 18-65-vuotiaita $(\mathrm{n}=107828)$.

Reini K, Tutkimusaineisto Saarela J.

Selvittää onko suomenja ruotsinkielisten välillä koostui $5 \%$ otoksesta suomenkielisistä ja $20 \%$ roa työhön paluussa
Selvittää osa-aikaisen sairauspoissaolon vaikutusta pysyvään työhön paluuseen ja työhön osallistumiseen.
Selvittää vuonna 2012 ta-ajan alussa (vuonna

Pysyvä työhön paluu oli todennäköisempää osa-aikaisen kuin kokoaikaisen sairauspoissaolon jälkeen. Täyden työkyvyttömyyseläkkeen esiintyvyys oli kokoaikaisella sairauspäivärahakaudella olleiden keskuudessa kolminkertainen verrattuna osa-aikaisiin. Vastaavasti osa-aikaisen työkyvyttömyyseläkkeen esiintyvyys oli 4,5-kertainen osa-aikaisella sairauspäivärahakaudella olleilla verrattuna kokoaikaisiin.

Työnantajien ilmoitusvelvollisuus pitkittyvistä sairauslomista ja työterveyshuollon lausuntovelvollisuus jäljellä olevasta työkyvystä ja mahdollisuuksista jatkaa työskentelemistä voivat edistää työhön paluuta lyhyellä aikavälillä otoksesta ruotsinkielisistä. Edelleen näitä otoksia rajattiin koskemaan niitä, jotka olivat saaneet Kelan sairauspäivärahaa ( $\mathrm{n}=242017$ ).
Kelan, ETK:n ja

rekisteriaineistot.
Työnantajien sairauspoissaolorekisterit.

2008

2011 ja

2013-

2014
Lakimuutos näytti edistävän työhön paluuta ja työhön osallistumista.

Vaikutukset olivat voimakkaammat naisille ja heille, joiden sairauspoissaolon syynä olivat mielenterveyden häiriöt.

Työkyvyttömyysjaksot olivat pitempiä niillä työntekijöillä, joilla oli määräaikainen työsuhde, kun vertailu tehtiin jatkuvassa työsuhteessa oleviin. Erityisesti tämä yhteys oli vahva matalan koulutuksen omaavilla ja iäkkäämmillä työntekijöillä.

Rekisteriaineisto vakeskuksen (ETK) rekisteriaineistot kon rajaamisessa. Tilastokeskuksen rekisteritiedot.

Työttömyys sairauspoissaolon jälkeen oli yleisempää suomenkielisille verrattuna ruotsinkielisiin. sairauspoissaolon jälkeen.
Tilastokeskuksen

1988 2010 rekisteriaineisto. sairauspäivärahakausista. Eläketurapuna tutkimusjou-

Työnantajien, 2005 Kelan, ETK:n ja

2010 ja PubMed

2013 2011 Scholar

PubMed
PubMed 
Saari P. (30) Tutkimus toteutettiin kuntoutuksessa olleita työntekijöitä haastattelemalla ja tekemällä työnantajien edustajille sähköinen kyselytutkimus (n (kuntoutujat) $=$ ei ilmoitettu, $\mathrm{n}=$ (työnantajat $)=45$, vastausprosentti 51).

Joensuu M, Tutkimus pohjautui Lindström "Impact of Changing SoK. (31) cial Structures on Stress and Quality of Life: individual and social perspectives"-projektissa kerättyyn aineistoon. Mukana analyysissa oli viisi eri maata: Itävalta, Irlanti, Hollanti, Suomi ja Iso-Britannia. Lopullisen tutkimusjoukon koko oli 554 henkilöä.

Laaksonen Tutkimukseen valittiin M, ym. (32) kaikki 30-64-vuotiaat, joille oli myönnetty (kokoaikainen) työkyvyttömyyseläke vuonna 2011 $(\mathrm{n}=17208)$.

Laaksonen Tutkimukseen valittiin M, ym. (33) kaikki 25-64-vuotiaat, joille oli myönnetty (kokoaikainen) työkyvyttömyyseläke mielenterveyssyistä vuonna $2011(\mathrm{n}=5544)$
Selvittää millaisia haasteita kuntoutujat kohtaavat työhön paluun ja työssä olemisen yhteydessä. Lisäksi tavoitteena oli tutkia myös työnantajien näkemyksiä, jotta voidaan arvioida työnantajien ja työntekijöiden näkemysten kohtaaminen.

Tutkia ovatko sairauspoissaoloihin yleisesti yhteydessä olevat tekijät keskeisiä myös työhön paluussa pitkän mielenterveysperusteisen sairauspoissaolon jälkeen.

Tutkia löytyykö työkyvyttömyyseläkkeen saajissa sairauspoissaolohistorian perusteella alaryhmiä ja eroavatko nämä alaryhmät toisistaan työkyvyttömyyseläkkeen syyn ja sosiodemografisten tekijöiden perusteella.

Tutkia ja kuvata sairauspoissaolohistoriaa ennen työkyvyttömyyseläkkeen myöntöä sekä kuinka sairauspoissaolo psyykkisistä ja somaattisista syistä ennustaa työkyvyttömyyseläkettä.
Esimiehen tuki on erittäin tärkeä työhön paluussa. Työhön paluun motivaatiolle on keskeistä, että työtehtävät ovat sopivan vaativia. Työhön paluun prosessi on usein varsin pitkä.

Työhön paluuta pitkän sairauspoissaolon jälkeen ennakoivat korkea koulutus, työpaikan suuri koko, perheellisyys ja työhön paluun yhdyshenkilön olemassaolo. Keskeinen tekijä on myös mielenterveysongelman tehokas, oikea-aikainen ja suunniteltu hoito.

Erilaisia sairauspoissaolopolkuja löytyi työkyvyttömyyseläkkeiden saajien keskuudessa.

Alaryhmiin jakautuminen oli sidoksissa työkyvyttömyyseläkkeen syyhyn mutta yhteydet sosiodemografisiin tekijöihin olivat heikot.

Sairauspäivärahan saajien osuus nousi tasaisesti ennen työkyvyttömyyseläkkeen nousua ja oli korkeimmillaan niiden keskuudessa, jotka saivat työkyvyttömyyseläkkeen masennuksen tai kaksisuuntaisen mielialahäiriön vuoksi. Mielenterveyssyistä työkyvyttömyyseläkkeelle jäävillä oli muita useammin sairauspoissaoloja sekä psyykkisistä että somaattisista syistä, mutta erityisesti mielenterveyssyistä pidetty sairauspäivärahakausi ennusti mielenterveysperustaista työkyvyttömyyseläkettä.

Pitkä sairauspoissaolo ennakoi vahvasti työky-

Rekisteriaineistot 2005, Tilastokeskuksesta, 2007myönnetyt sairauspäivärahakaudet ennustavat työkyvyttömyyseläkettä ammattiluokka huomioiden.
Kelan rekisteriaineisto sairauspäi- 2011 värahakausista ja Kelan sekä ETK:n rekisteriaineisto työkyvyttömyyseläkkeistä.
Haastattelu- ja

$\begin{array}{lll}\text { Kyselyaineisto } & 2004- & \begin{array}{l}\text { Vertais- } \\ \text { arvoijan } \\ \text { suositus }\end{array}\end{array}$

Kelan rekisteriai-

20012011 Kelan sekä ETK:n rekisteriaineisto työkyvyttömyyseläkkeistä.

\section{PubMed}

PubMed
Salonen L, Tutkimusaineisto koos tyneitä 25-62-vuotiaita vuodelta 2006 ( $\mathrm{n}=1727644$ ). 
Kausto J, Tutkimusjoukko muoym. (35) dostettiin kokonaisotoksesta osasairauspäivärahaa 1.8.2007-31.1.2008 välisenä aikana saaneista $(\mathrm{n}=1016)$.

Kausto J, Tutkimukseen valittiin ym. (36) kaikki, jotka olivat saaneet osa- tai kokoaikaista sairauspäivärahaa vuoden 2007 aikana ( $\mathrm{n}=29427)$. Tutkittavien seuranta-aika oli keskimäärin 18 kuukautta.
Selvittää yleisesti ketkä ovat saaneet osasairauspäivärahaa, miten järjestelmä toimii asiakkaiden näkökulmasta ja missä määrin on palattu kokoaikaiseen työhön osasairauspäivärahakauden jälkeen.

Tutkia Kelan korvaamien sairauspäivärahakausien toistumista ja osa-sekä kokoaikaisen työkyvyttömyyseläkkeen esiintymistä. Vertailuissa huomioitiin osa-aikainen ja kokoaikainen sairauspäiväraha.
Kausto J, ym. (37)

Reho TTM, Tutkimusjoukko koostui ym. (38) Pihlajalinnan työterveyshuollon 18-68-vuotiaista asiakkaista $(\mathrm{n}=59676)$,
Perhoniemi Tutkimuksen kohdeR, ym. (40) joukko muodostui $70 \%$ otoksesta vuoden 2010 aikana hylkäävän työkyvyttömyyseläkepäätöksen saaneista, jotka olivat 18-58-vuotiaita $(\mathrm{n}=4536)$.

Perhoniemi Tutkimukseen valittiin R, ym. (41) 18-58-vuotiaat, jotka olivat saaneet ensimmäisen hylkäävän työkyvyttömyyseläkepäätöksen vuonna $2010(\mathrm{n}=3683)$.
Tutkia osa-aikaisen sairauspäivärahan vaikutusta työkyvyttömyyseläkkeelle siirtymiseen hyödyntämällä vastaavuuspistemääriin perustuvaa kaltaistusta (propensity score approach).

Tutkia onko työkyvyttömyyseläkkeen riski yhteydessä usein tapahtuvaan terveydenhuollon palvelujen käyttöön.

Lisäksi tutkia eroavatko satunnaisesti ja jatkuvasti paljon palveluja käyttävät toisistaan suhteessa työkyvyttömyyseläkkeen riskiin.

Tutkia sosiaalietuuksien ja uusien työkyvyttömyyseläkepäätösten yleisyyttä hylätyn työkyvyttömyyseläkehakemuksen jälkeen.

Selvittää sekvenssianalyysillä tulonlähdepolkuja hylätyn työkyvyttömyyseläkepäätöksen jälkeen ja näihin polkuihin sidoksissa olevia tekijöitä kuten sosiodemografisia tekijöitä.
Kokemukset osasairauspäivärahasta olivat pääosin myönteisiä. $80 \%$ vastaajista koki etuuden edistäneen toipumista ja kaksi kolmesta palasi osasairauspäivärahakauden jälkeen kokoaikaiseen työhön.

Noin $60 \%$ osa-aikaisella ja $30 \%$ kokoaikaisella sairauspäivärahalla olevista oli ainakin yksi uusiutuva sairauspoissaolojakso seurantajakson aikana. Kun osa-aikaista sairauspäivärahaa ei seuraa pysyvä työhön paluu, on osa-aikaisen työkyvyttömyyseläkkeen riski suurempi kuin kokoaikaisen työkyvyttömyyseläkkeen.

Osa-aikainen sairauspäiväraha vähensi täyden työkyvyttömyyseläkkeen riskiä $6 \%$ ja lisäsi osa-aikaisen työkyvyttömyyseläkkeen riskiä $8 \%$ verrattuna kokoaikaiseen sairauspäivärahaan.

Sekä satunnaisesti että jatkuvasti paljon terveydenhuollon palveluja käyttävillä oli suurempi työkyvyttömyyseläkkeen riski kuin keskimääräisellä työterveyshuollon palvelujen käyttäjällä. Koholla oleva työkyvyttömyyden riski johtui suurelta osin edeltävistä sairauspoissaolopäivistä.

Hylkäävän eläkepäätöksen jälkeiset etuuskaudet (kuten työttömyys- ja sairauspäiväraha) ovat yleisiä samoin kuin työkyvyttömyyseläkkeen hakuprosessin jatkuminen.

Pääasialliset tulonlähteet hylätyn työkyvyttömyyspäätöksen jälkeen ovat työttömyyskorvaukset, uudelleen haettu työkyvyttömyyseläke sekä katkonaiset työtulot. Työmarkkina- ja sairaushistorialla sekä iällä on merkitystä mihin tulonlähderyhmään kuuluu.
Kyselyaineisto

2007ja aineistoon 2008 yhdistetyt Kelan rekisteritiedot sairauspäivärahakausista.

Kelan rekisteri-

2007 aineisto sairauspäivärahakausista ja Kelan sekä ETK:n rekisteriaineisto työkyvyttömyyseläkkeistä.

Kelan rekisteriaineisto sairauspäivärahakausista ja rekisteriaineisto työkyvyttömyyseläkkeistä.

1.5. PubMed 2007 31.12 . 2008

Pihlajalinnan

2014 2016 ja 2015aineisto ja ETK: rekisteritiedot työkyvyttömyyseläkkeistä.

Kelan, ETK:n ja 2010Tilastokeskuksen 2014 rekisteriaineistot.

Rekisteriaineis-

2010-

PubMed tot eri etuuksien 2014
PubMed työttömyys- ja kuntoutusrahatiedot) saamisesta ja ETK:n ja Kelan tiedot eläkeratkaisuista. 
Nwaru CA, Tutkimukseen valittiin ym. (42) 18-60-vuotiaita
pitkäaikaistyöttö pitkäaikaistyöttömiä, jotka olivat osallistuneet puolen vuoden pituiseen tuettuun työllistymisohjelmaan ( $\mathrm{n}=18944)$.

Tämä tutkimusjoukko kuuluu suomalaiseen julkisen sektorin tutkimusaineistoon (FPS).
Selvittää sairauspoissa- Sairauspoissaolo tuetun olojen ja työmarkkinoille työllistymisohjelman kiinnittymisen yhteyksiä.

aikana lisäsi heikon työmarkkinakiinnittymisen riskiä. Riski oli erityisen korkea nuorille, joilla oli yli 30 päivän mittainen sairauspoissaolo.
ETK:n rekisteriaineisto työhistoriasta ja Kelan rekisteriaineisto sairauspäivärahakausista.
1994-

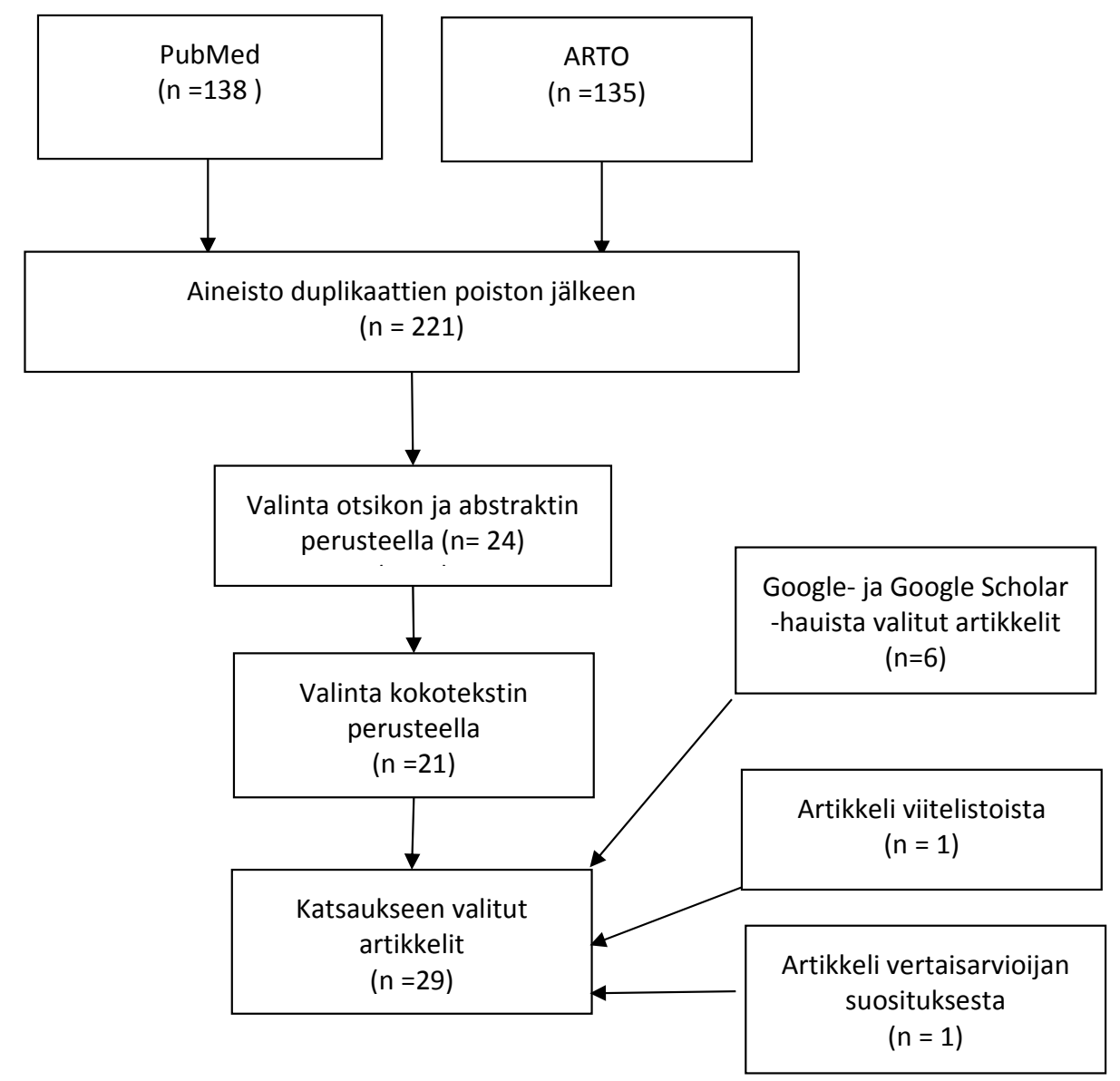

Kuvio 1. Julkaisujen valintaprosessi. 


\section{TYÖHÖN PALUU SAIRAUSPOISSAOLON JÄLKEEN}

Sairauspoissaolon toivottu lopputulema on työkyvyn palautuminen ja työhön paluu. Työhön paluun onnistumiseen vaikuttavia tekijöitä on tutkittu erityisesti mielenterveyden häiriöiden ja tuki- ja liikuntaelinsairauksien yhteydessä. Esimerkiksi masennuksen jälkeiseen työhön paluun menestyksellisyyteen voivat vaikuttaa monet tekijät. Somaattinen ja psyykkinen yhteissairastavuus sekä masennuksen vakavuusaste ovat yhteydessä epätodennäköisempään työhön paluuseen (16, 17). Iällä on merkitystä, sillä vanhemmilla työntekijöillä työhön paluu masennuksen sairastamisen jälkeen on vaikeampaa kuin nuoremmilla työntekijöillä $(16,18)$. Korkean ammatillisen aseman on osoitettu olevan yhteydessä nopeampaan työhön paluuseen masennuksen jälkeen (16). Psykososiaaliseen työympäristöön liittyen on havaittu, että parempi kontrolli työtehtävien suhteen helpottaa ja puolestaan työn kuormittavuus hidastaa työhön paluuta (16).

Mielenterveyden häiriöiden ja tuki- ja liikuntaelinsairauksien vuoksi sairauspäivärahakaudella olleiden pysyvää työhön paluuta on arvioitu Kuntasektorin henkilöstön seurantatutkimuksen aineistolla, joka koostuu viidenneksestä Suomessa julkisella sektorilla työskentelevistä (19). Tutkimuksen tavoitteena oli selvittää sairauspoissaolon pituuden ja pysyvän työhön paluun yhteyttä sekä sitä ennustavia tekijöitä. Työhön paluu luokiteltiin pysyväksi, mikäli uusi sairauspoissaolo ei alkanut työhön paluun jälkeen 30 päivän kuluessa. Puolet sairauspoissaolojaksoista päättyi pysyvään työhön paluuseen 21-46 päivän kuluttua riippuen työkyvyttömyyden diagnoosista. Masennuksen ja nikamavälilevyjen sairauksissa sairauspoissaolojen kesto oli keskimäärin kuusi viikkoa ja ahdistushäiriöissä ja selkäkivun yhteydessä poissaolo oli keskimäärin kolme viikkoa. Korkeampi ikä, pitkäkestoinen terveysongelma ja sairauksien yhteisesiintyvyys ennustivat pitempää aikaa ennen pysyvää työhön paluuta. Työhön paluussa ei ollut eroja sukupuolten välillä lukuun ottamatta masennusta. Naisilla masennuksesta johtuva sairauspoissaolo oli lyhyempi kuin miehillä (38 päivää vs. 46 päivää). Kuntatyöntekijöiden seurantatutkimuksen tuloksia on lisäksi raportoitu yksityiskohtaisemmin Työterveyslaitoksen raportissa (20). Molemmat julkaisut $(19,20)$ korostavat, että tulokset olivat pää- piirteittäin yhdenmukaisia sairauspoissaolojen kestoa koskevien ohjeiden kanssa.

\section{OSA-AIKAISEN SAIRAUSPOISSAOLON VAIKUTUS TYÖHÖN PALUUSEEN}

Osa-aikaisen sairauspoissaolon on osoitettu tukevan tuki- ja liikuntaelinsairauden jälkeistä työhön paluuta (21). Osa-aikaisella sairauspoissaolokaudella olleet palasivat nopeammin kokoaikaiseen työhön ja heillä oli myös vähemmän toistuvia sairauspoissaolokausia. Seurantatutkimuksessa osoitettiin, että osittainen sairauspoissaolo ei lisännyt tuki- ja liikuntaelinsairauksien oireita taikka toimintakyvyttömyyttä (22). Positiivinen löydös oli, että osa-aikaisesti sairauden takia poissaolleilla itsearvioitu terveys koheni samoin kuin terveyteen liittyvä elämänlaatu verrattuna kokoaikaisesti sairauspäivärahakaudella olleisiin. Nämä tulokset korostavat ensimmäisen hoitokäynnin ja poissaoloasteen valinnan tärkeyttä sairauspoissaolon pitkittymisen ehkäisemisen kannalta. On huomattava myös, että osittainen sairauspoissaolo ei välttämättä ole kokoaikaista vaikuttavampi, jos tuki- ja liikuntaelinsairaus on pitkäkestoinen tai työkyky merkittävästi alentunut.

Osasairauspäiväraha vaikuttaa tukevan erityisesti mielenterveyssyistä työkyvyttömänä olevien työhön paluuta $(23,24)$. Osasairauspäivärahan ehtona on osa-aikainen työskentely, mikä merkitsee, että henkilöllä on pysyvämpi työsuhde ja näin ollen paremmat edellytykset työhön osallistumiseen. Osasairauspäiväraha voi olla jopa parempi vaihtoehto kuin kokoaikainen sairauspäiväraha, jos työtä voidaan sopeuttaa työja toimintakyvyn mukaan, sillä uudelleen työllistyminen mielenterveysperusteisen sairauspoissaolon jälkeen voi olla vaikeaa.

\section{VUODEN 2012 LAKIMUUTOKSET}

Työnantajan ilmoitusvelvollisuus työterveyshuoltoon pitkistä sairauspoissaoloista ja lausuntovelvollisuus jäljellä olevasta työkyvystä kolmen kuukauden sairauspoissaolon jälkeen ovat molemmat uudistuksia, joiden tarkoituksena on työhön paluun nopeuttaminen ja työhön osallistumisasteen nostaminen. Tulokset näiden uudistusten vaikutuksista ovat osittain ristiriitaisia. Kuntasektorin seurantatutkimuksen aineistolla tehty tutkimus on osoittanut, että lyhyellä aikavälillä pysyvä työhön paluu on noussut jonkin verran, kun 
vertailtiin ajanjaksoja 2010-2011 ja 2013-2014 (25). Toisessa tutkimuksessa, jossa aineistona oli 70 prosentin otos suomalaisesta työikäisestä väestöstä vuosilta 2010 ja 2013, saatiin samansuuntaiset tulokset (26). Pysyvä työhön paluu ja työhön osallistumisaste nousivat lakimuutoksen jälkeen. Myönteiset vaikutukset olivat suuremmat naisille ja heille, joiden sairausloman taustalla olivat mielenterveyssyyt. Suhteellinen muutos työhön osallistumisessa oli suurin heillä, jotka asuivat alhaisen työttömyyden alueilla tai työskentelivät julkisella sektorilla.

Samalla aineistolla tehty kuin edeltävä tutkimus (26) ja osin myös samojen tutkijoiden tekemä työ osoitti, että lakimuutokset eivät lyhentäneet työhön paluuseen kuluvaa aikaa taikka nostaneet työhön osallistumisastetta (5). Osittaisten työkyvyttömyysetuuksien käyttö lisääntyi verrattuna kokoaikaisiin työkyvyttömyysetuisuuksien käyttöön ja kuntoutuksessa kulunut aika puolitoistakertaistui. Seuranta-aika oli tässä tutkimuksessa (5) suhteellisen lyhyt (10 kk), jolloin lisääntyneen kuntoutusetuuksien käytön vaikutukset työhön osallistumiseen eivät tule riittävästi esille. Tutkijat korostavat, että erot tutkimustulosten välillä voivat johtua aineiston erilaisesta rajauksesta. Työhön kiinnittymisen määritelmät olivat tutkimuksissa erilaiset ja samoin sairauspoissaolojen pituus laskettiin eri tavoin. Lakimuutoksen vaikutuksen arvioimista saattavat vaikeuttaa lisäksi taloudellisessa tilanteessa tapahtuneet muutokset. Tutkimusajalle osuu lama ja entuudestaan tiedetään, että talouden syklin vaihe vaikuttaa sairauspoissaolokäyttäytymiseen (27).

\section{MUITA TYÖHÖN PALUUSEEN VAIKUTTAVIA TEKIJÖITÄ}

Työhön paluu ei ainoastaan riipu sairaudesta, yksilöön tai terveyteen liittyvistä asioista vaan myös elin- ja työskentelyolosuhteista sekä kulttuurisista ja organisaatiota koskevista tekijöistä (16). Märäaikaisessa työsuhteessa oleminen hidastaa työhön paluuta masennuksen jälkeen (16). Määräaikaisten työntekijöiden työkyvyttömyysjaksojen on havaittu olevan pitempiä kuin pysyvässä työsuhteessa olevien (28). Ilmiö oli voimakkain iäkkäämmillä työntekijöillä ja matalasti koulutetuilla. Pysyvä työsuhde voi antaa turvaa sairauspoissaolon jälkeiseltä työttömyydeltä sekä kokonaan työmarkkinoilta poistumiselta. Keskeisessä asemassa työkyvyn arvioinnissa ja oikea-aikaisessa kuntoutuksessa ovat työterveyshuollon pal- velut, joihin epätyypillisissä tai määräaikaisissa työsuhteissa olevilla käyttöoikeus voi katketa. Kieliryhmiä toisiinsa vertailtaessa on havaittu, että ruotsinkielisillä työhön paluu sairauspoissaolon jälkeen onnistuu paremmin kuin suomenkielisillä (29). Tämä mahdollisesti heijastelee kulttuuriin sidoksissa olevien tekijöiden vaikutusta, sillä molemmilla ryhmillä ovat yhtäläiset oikeudet terveydenhuoltoon ja työkyvyttömyysetuisuuksiin.

Saaren artikkeli (30) nostaa esille julkisen sektorin työntekijöiden ja työnantajien näkemyksiä haasteista ja ratkaisukeinoista, jotka liittyvät sairauspoissaolon jälkeiseen työhön paluuseen. Työntekijöiden näkökulmasta suurimmat haasteet liittyivät työnantajan tarjoaman tuen riittävyyteen, kuntoutuksen ja työhön paluun oikeaaikaisuuteen ja suunnitelmallisuuteen sekä työnkuvan muokkaamiseen. Työhön paluu voi olla hyvin paljolti riippuvainen siitä, kuinka työpaikan olosuhteita ja työnkuvaa pystytään mukauttamaan esimerkiksi osittaiseen työkykyyn sopivaksi. Työntekijät mainitsivat myös, että rasitteeksi voi muodostua epävarman työntekijän leima johtuen työkyvyttömyysjaksosta tai epämotivoiviin tehtäviin joutuminen. Työnantajat nostavat esille haasteina esimiesten tarjoaman tuen riittävyyden, työntekijän motivaation, työntekijän alhaisen koulutustason, sairauden pitkittymisen sekä vaikeudet yhteistyössä eri toimijoiden kesken. Ratkaisukeinoina sujuvampaan työhön paluuseen nähtiin henkilöstöhallinnon aktiivisempi rooli, koulutuksen ja tiedotuksen lisääminen sekä yhteistyön parantaminen ja vastuunjaon selkeyttäminen eri osapuolten välillä. Myös muissa tutkimuksissa on havaittu työhön paluun koordinoinnin olevan merkittävässä roolissa, sillä työhön paluun yhdyshenkilön olemassaolo ennakoi työhön paluuta mielenterveysperusteisen pitkän sairauspoissaolon jälkeen (31).

Ervasti ja kollegat huomauttavat (16), että työhön paluun prosessi sairauspoissaolon jälkeen näyttää olevan melko samanlainen sairaudesta riippumatta, sillä useat työhön paluuseen vaikuttavat tekijät ovat yleisluontoisia. Esimerkiksi korkeaan koulutukseen voi sisältyä resursseja, jotka saattavat helpottaa sopeutumista sairauden aiheuttamiin muutoksiin työssä. Lisäksi korkeasti koulutetuille voi olla työmarkkinoilla enemmän kysyntää, mikä voi edistää työhön paluuta sairauspoissaolon jälkeen. Kuitenkin työ- 
hön liittyvät ihmissuhteet näyttäytyvät tärkeämpinä mielenterveyteen liittyvän työkyvyttömyysjakson kuin somaattisesta syystä johtuvan poissaolon jälkeen (16). Tästä voi kertoa se, että suurempaan työpaikkaan on helpompi palata sairauspoissaolon jälkeen (31).

\section{TYÖKYVYTTÖMYYSELÄKKEEN RISKI}

Sairauspoissaolokausien ja työkyvyttömyyseläkkeiden yhteyksiä sekä sairauspoissaolohistorian piirteitä, jotka ennustavat työkyvyttömyyseläkettä, on selvitetty runsaasti. Tutkittaessa työkyvyttömyyseläkettä edeltäviä sairauspoissaoloja hyvin heterogeenisiä kehityspolkuja oli havaittavissa (32). Kehityspoluilla oli jonkin verran yhteyttä siihen, mikä diagnoosi oli työkyvyttömyyseläkkeen takana, mutta vain vähäinen yhteys sosiodemografiseen taustaan. Sairauspoissaolopäivät näyttivät selkeästi lisääntyvän useissa kehityspoluissa jo muutamia vuosia ennen työkyvyttömyyseläkkeen myöntöä. Lisätutkimusta tarvittaisiin näiden työkyvyttömyyseläkettä edeltävien sairauspoissaolopolkujen selvittämiseen, jotta pitkittyvät työkyvyttömyysjaksot voitaisiin tunnistaa aikaisessa vaiheessa.

Mielenterveyssyistä sairauspäivärahaa saaneilla nähdään jo useita vuosia ennen eläkkeelle jäämistä kohonnut riski työkyvyttömyyseläkkeeseen, jonka syynä on mielenterveyden häiriö (33). Erityisesti mielenterveyssyistä johtuva sairauspoissaolo ennusti työkyvyttömyyseläkettä mielenterveysdiagnoosilla. Myös somaattinen sairauspäivärahakauden syy nosti mielenterveysperusteisen työkyvyttömyyseläkkeen riskiä, mutta huomattavasti vähemmän kuin mielenterveysperusteinen sairauspoissaolo. Tämä mahdollisesti heijastaa mielenterveyshäiriöiden ja somaattisten sairauksien yhteisesiintyvyyttä ja jälkimmäisten sairauksien helpompaa tunnistamista.

Ammattiryhmäkohtaiset erot ovat havaittavissa työkyvyttömyyseläkkeelle johtavissa poluissa (34). Sairauspoissaolon pituus ennustaa vahvemmin työkyvyttömyyseläkettä kuin sairauspoissaolon syy kaikissa ammattiluokissa. Huomattava on, että diagnoosiprofiilit vaihtelevat ammattiluokittain, mikä osittain selittää myös yhteyden sairauspoissaolon pituuden ja työkyvyttömyyseläkkeen välillä. Samassa tutkimuksessa havaittiin lisäksi, että mielenterveyssyistä pidetyn sairauspoissaolon pituus ennusti työkyvyttömyyseläkettä voimakkaammin kuin muilla diag- nooseilla pidetty sairauspoissaolon pituus ja näin etenkin ylempien toimihenkilöiden tapauksessa. Tutkijat (34) ehdottavat tämän voivan johtua työhön liittyvistä tekijöistä. Ylemmillä toimihenkilöillä on usein psyykkisesti vaativa työ ja työnantajat voivat haluta työntekijän olevan täysin toipunut ennen työhön paluuta. Henkisesti kuormittavaan työhön voi olla vaikea palata, jos toipuminen mielenterveyden häiriöstä on vielä kesken. Lisäksi työn psyykkisten vaatimusten muokkaaminen voi olla suhteessa vaikeampaa kuin työn fyysisten vaatimusten.

\section{OSA-AIKAISEN SAIRAUSPOISSAOLON VAIKUTUS TYÖKYVYTTÖMYYSELÄKKEEN RISKIIN}

Osasairauspäivärahakaudella on havaittu olevan niin objektiivisia kuin subjektiivisia positiivisia vaikutuksia. Kyselytutkimus on vahvistanut osasairauspäivärahalla olleiden kokemukset etuuden käytöstä olevan pääasiassa myönteisiä (35). Osasairauspäivärahakautta näyttää seuraavan useammin osa-aikainen kuin kokoaikainen työkyvyttömyyseläke, jos osasairauspäivärahakautta ei seuraa pysyvä työhön paluu (36). Osa-aikaisen sairauspoissaolon on havaittu olevan erityisen hyödyllinen keski-ikäisille ja iäkkäämmille työntekijöille (45-65-vuotiaat), sillä se nosti heidän työhön osallistumista suhteessa enemmän kuin nuorten työntekijöiden (23).

Yksityiskohtaisemmassa osasairauspäivärahan vaikutusten tutkimuksessa havaittiin osasairauspäivärahan vähentävän kokoaikaisen työkyvyttömyyseläkkeen riskiä kuudella prosentilla ja lisäävän osa-aikaisen työkyvyttömyyseläkkeen riskiä kahdeksan prosenttia verrattuna kokoaikaiseen sairauspäivärahaan (37). Miehillä täyden työkyvyttömyyseläkkeen riski pieneni jopa 10 prosenttia. Päädiagnoosiryhmien, mielenterveyden häiriöiden ja tuki- ja liikuntaelinsairauksien, osalta ei havaittu eroja riskien suuruudessa. Verrattuna ensimmäiseen osasairauspäivärahan ja työkyvyttömyyseläkkeen yhteyksien tutkimukseen (36) tässä tutkimuksessa (37) kontrolloitiin paremmin mahdollinen osasairauspäivärahan valikoiva vaikutus. Tulosten osalta on kuitenkin huomattava, että osasairauspäivärahakausien määrä oli aineistossa varsin pieni ja seuranta-aika lyhyt. Tutkijoilta puuttui lisäksi tieto työkyvyttömyyseläkkeiden syistä, mikä rajoittaa johtopäätösten tekemistä.

Osasairauspäivärahan tehokkuutta on lisäksi tutkittu mielenterveyshäiriöiden tai tuki- ja lii- 
kuntaelinsairauksista johtuvien työkyvyttömyyskausien alussa (24). Kahden vuoden seurannassa havaittiin työhön osallistumisasteen olevan korkeampi ja sairauspoissaoloja sekä työkyvyttömyyseläkkeitä olevan vähemmän osasairauspäivärahalla olleilla verrattuna kokoaikaisella sairauspäivärahalla olleisiin. Myönteiset vaikutukset olivat suurempia mielenterveyssyistä työkyvyttömänä olleille. Osasairauspäivärahan huomattiin nostavan osa-aikaisen työkyvyttömyyseläkkeen riskiä erityisesti sosiaali- ja terveyssektorilla, vaikka se vähensi täyden työkyvyttömyyseläkkeen ja työttömyyden riskiä

\section{TYÖTERVEYSHUOLLON ROOLI}

Työterveyshuollolla on mahdollisuudet havaita ajoissa toistuvasti ja usein terveydenhuollon palveluja käyttävät. Tuore tutkimus on osoittanut, että sekä satunnaisesti että jatkuvasti paljon työterveyshuollon palveluja käyttävillä on kohonnut työkyvyttömyyseläkkeen riski verrattuna keskimääräiseen työterveyshuollon palvelujen käyttäjään (38). Tämä kytkös on yhteydessä lisääntyneisiin sairauspoissaoloihin. Tulokset vahvistavat näkemystä, että työterveyshuollon rooli kuntoutuksen aloittamisessa on keskeinen, kun halutaan ennaltaehkäistä sairauspoissaolojen kehittymistä ja pitkittymistä. Palvelujen käyttöä seuraamalla olisi mahdollista identifioida aikaiseen kuntoutukseen valittavat ainakin mielenterveysongelmien ja tuki- ja liikuntaelinsairauksien osalta.

\section{LOPUKSI}

Sairauspoissaolot ja työkyvyttömyyseläkkeet kertovat paljon työikäisen väestön terveydentilasta. Tutkimuksen jatkaminen runsaslukuisena ja monesta eri näkökulmasta on hyvin perusteltavissa, sillä sairauspoissaolokäyttäytymiseen ja työkyvyttömyyseläkkeelle hakeutumiseen vaikuttavat monet tekijät, joista osa on yhteydessä suoraan yksilöön ja osa koko yhteiskunnan tilanteeseen. Työkyvyttömyyteen liittyvän tutkimuksen merkitys päätöksenteolle on ilmeinen. Sosiaaliturvajärjestelmämme kohdistuu muutospaineita ja julkisuudessa on paljon keskusteltu koko sosiaaliturvan uudistamisesta kokonaisuutena. Jää nähtäväksi missä laajuudessa tässä uudistuksessa käsitellään myös sairauteen ja työkyvyttömyyteen liittyviä etuuksia. Tiedämme ainakin, että vähimmäissairauspäivärahan varassa olevilla toimeentulotukeen turvautuminen on ollut yleistä (39).
Työelämä ja työsuhteiden laatu on muuttunut paljon viime vuosien aikana. Pätkä- ja osa-aikatöitä tehdään entistä enemmän ja samanaikaisesti voi olla voimassa useita työsuhteita. Yksi esimerkki sosiaaliturvaan liittyvästä problematiikasta on epävarmoissa työsuhteissa olevien ja työttömien työhön paluu sairauspoissaolon jälkeen. Heitä eivät tavoita työterveyshuollonpalvelut tai niiden piiriin kuuluminen voi päättyä. Jos päädytään hakemaan työkyvyttömyyseläkettä ja hakemus hylätään, edessä voi olla etuuskierre, jossa vuorottelevat sairaus- ja työttömyyspäivärahakaudet $(40,41)$. Myös eläminen muiden tukien varassa voi yleistyä ja mahdollisuudet kuntoutukseen vähentyä, jolloin seurauksena voi olla pysyvä työkyvyn heikkeneminen. Työttömien työkyvyn seuranta on pitkälti työttömien oman aktiivisuuden varassa. Tiedetään, että pitkäaikaistyöttömillä, joilla on lisäksi pitkiä sairauspoissaoloja, on vaikeuksia työmarkkinoille kiinnittymisessä ja työllistymisessä (42). Työttömyys ja sairaus muodostavat näin kaksoistaakan, joka vaikeuttaa merkittävästi työhön paluuta. Tarvitaan tutkimusta, jotta voidaan arvioida, tarvitseeko työhön paluu interventioiden keskittyä esteiden poistamiseen työn säilyttämisen tai saamisen puolesta vai keskittyä esimerkiksi terapian saatavuuteen ja tehokkuuteen masennusta sairastavien määräaikaisten työntekijöiden kohdalla (28).

Sairauspäivärahajärjestelmää koskevista 2000luvun uudistuksista on kulunut nyt sen verran aikaa, että pidemmät seurantatutkimukset ovat mahdollisia. Lisätutkimukset ovat tarpeen ainakin osasairauspäivärahan osalta useasta syystä. Ensinnä, osasairauspäivärahaa koskevat säännökset ovat muuttuneet sen voimaantulon eli vuoden 2007 jälkeen. Osasairauspäivärahan käyttömahdollisuuksia laajennettiin vuonna 2010, mikä merkitsi, että osasairauspäivärahaa on voinut saada heti sairauspäivärahan omavastuuajan jälkeen. Vuonna 2014 osasairauspäivärahan maksamisen enimmäisaika pidentyi 72 arkipäivästä 120 arkipäivään. Tehdyt muutokset näkyvät selkeästi pidettyjen osasairauspäivärahakausien määrissä, sillä vuosina 2010 ja 2014 osasairauspäivärahakausien määrissä suhteessa kaikkiin sairauspäivärahakausiin on selkeä nousu. Toiseksi, kausien yleistyminen on ollut verrattain hidasta. Vuonna 2018 osasairauspäivärahakausia oli 7,2 prosenttia kaikista sairauspäivärahakausis- 
ta. Kolmanneksi osasairauspäivärahan käytössä on selkeä ero sukupuolten välillä, sillä 75 prosenttia osasairauspäivärahalla olevista on naisia. Miksi miehet käyttävät vähemmän tätä etuutta? Tutkimus (37) on kuitenkin osoittanut osasairauspäivärahan hyötyjen olevan suuremmat miehille kuin naisille.

Lainsäädännön muutosten taloudellisia vaikutuksia tulisi seurata resurssien tehokkaan ja vaikuttavan käytön vuoksi. Esimerkiksi osasairauspäivärahan tiedetään kerryttävän säästöjä (4). Tuki- ja liikuntaelin sairauksien sekä mielenterveyden häiriöiden vuoksi sairauspäivärahakaudella olleiden kahden vuoden seurannassa havaittiin osasairauspäivärahakaudella olleella vuotuisten sosiaaliturvakustannusten olevan 2395 euroa pienemmät kuin kokoaikaista sairauspäivärahaa saavalla. Suurimmat säästöt muodostuivat eläköitymisen ja ammatillisen kuntoutuksen kustannuksista.

Pitkät seurantatutkimukset ovat tarpeellisia selvitettäessä kuntoutusetuisuuksien lisääntyneen käytön vaikutuksia. Tietoa tarvitaan etenkin tehokkaista toimenpiteistä tai niiden yhdistelmistä, jotka aidosti edistävät työhön paluuta tai vähentävät työkyvyttömyyseläkkeen riskiä. Työkyvyttömyyseläke ja työttömyys ovat yleisiä jo ennen ammatillista kuntoutusta, mikä tarkoittaa, että kuntoutus ei ole toteutunut työkyvyttömyyden alkamisen alkuvaiheissa (43). Kuntoutuksen tulisi alkaa siis nykyistä varhemmin ja toimenpiteiden tulisi olla koordinoituja työllistä- mistoimien kanssa, jotta kuntoutuksen jälkeinen työttömyys vähenisi. Lisäksi kuntoutusryhmien erilaisuus tulisi huomioida, sillä joillakin ryhmillä voi olla erityisiä haasteita työn osalta tai itse työllistymisessä kuntoutuksen jälkeen. Mielenterveysongelmien on osoitettu olevan yhteydessä heikompiin työhön osallistumispolkuihin ammatillisen kuntoutuksen jälkeen (43). Lisäksi ammatillisen kuntoutuksen on havaittu edistävän vain vähän naisten, joilla on tuki- ja liikuntaelinsairauksia, työhön paluuta (44).

Tämä artikkeli keskittyi erityisesti sairauspoissaolon jälkeiseen työhön paluuseen ja työkyvyttömyyseläkkeen riskiin sekä sairausvakuutusjärjestelmäämme tehtyihin viimeaikaisiin muutoksiin, jotka koskevat sairauspäivärahaa. Tähän katsaukseen valitut artikkelit osoittavat, että Suomessa on tehty paljon ajankohtaista tutkimusta ja lainsäädännöllisten muutosten vaikutuksia on seurattu. Saadut tulokset peilaavat vakuutusjärjestelmämme toimivuutta ja toisaalta antavat viitteitä kehityskohteista. Lisää tietoa tarvitaan ainakin tehokkaista kuntoutustoimenpiteistä, jotka tukevat työhön paluuta, sekä osasairauspäivärahan vaikutuksista.

\section{KIITOKSET:}

Asiantunteville vertaisarvioitsijoille.

\section{RAHOITTAJA:}

Svenska litteratursällskapet i Finland

Reini, K. Return to work and risk of disability pension after sickness absence. Review of Finnish studies 2008-20I9. Sosiaalilääketieteellinen aikakauslehti - Journal of Social Medicine 2020: 57: I68- 184.

Sickness absence and work disability research are common in Finland. There are several reasons for this, the obvious ones being the significance to the society and the extensive register data about sickness benefits. The sickness absence legislation and insurance system often differ between countries that limit the application of the results of international studies. This emphasizes the importance of national research to support decision-making processes. In Finland, several legislative changes to sickness absence have been executed that aim faster return to work and fewer disability pensions. Research on sickness allowance is necessary because our social security system is under pressure to change. This review focuses on recent Finnish sickness absence research that deals with return to work and risk of disability pension. Altogether 29 publications, that many used register-based data, were selected to this review. Return to work after sickness absence has been studied especially in the context of musculoskeletal disorders and mental health problems. For both diagnostic groups, part-time sickness absence is positively associated with return to work. However, also other factors than illness, individual and health play a role in return to work. Living and working conditions and cultural and organization related factors are also important. There are various sickness absence paths to disability pension. Some of the differences can be ex- 
plained by the diagnose of disability pension and occupation. Part-time sickness absence reduces the risk of full disability pension and increases the risk of part-time disability pension. It would be useful to continue to investigate the effects of part-time sickness allowance, as the use of parttime sickness allowance has been slowly increasing and there is a substantial gender difference. In addition, information on effective rehabilitation interventions that promote the return to work is

\section{LÄHTEET}

(1) Allebeck P, Mastekaasa A. Risk factors for sick leave - general studies. Scand J Public Health 2004; Suppl 63:49-108.

(2) Kansaneläkelaitos. Kelan tilastollinen vuosikirja 2017. Luettu 13.3.2019. https://helda.helsinki. fi/bitstream/handle/10138/270222/Kelan_ tilastollinen_vuosikirja_2017.pdf?sequence=21

(3) Kaikkonen R, Härkänen T, Rahkonen O, ym. Explaining educational differences in sickness absence: a population-based follow-up study. Scand J Work Environ Health 2015;41:338-346.

(4) Viikari-Juntura E, Leinonen T, Virta LJ, ym. Early part-time sick leave results in considerable savings in social security costs at national level: an analysis based on a quasi-experiment in Finland. Scand J Work Environ Health 2019;45:203-208.

(5) Viikari-Juntura E, Virta L, Leinonen T, ym. Kuntoutus- ja osittaisten työkyvyttömyysetuuksien käyttö lisääntyy - miten työssäolo. Duodecim 2017;133:16551663.

(6) Sumanen H, Pietiläinen O, Lahelma E, ym. Short sickness absence and subsequent sickness absence due to mental disorders - a follow-up study among municipal employees. BMC Public Health. 2017;17:15.

(7) Vahtera J, Pentti J, Kivimäki M. Sickness absence as a predictor of mortality among male and female employees. J Epidemiol Community Health 2004;58:321-326.

(8) Virtanen M, Kivimäki M, Elovainio M, ym. Local economy and sickness absence: prospective cohort study. J Epidemiol Community Health 2005;59:973-978.

(9) Eläketurvakeskus. Työkyvyttömyyseläke. Luettu 6.11.2019. https://www.etk.fi/ elakejarjestelmat/elaketurva/tyoelake-etuudet/ tyokyvyttomyyselake

(10) Eläketurvakeskus. Tilasto Suomen eläkkeensaajista 2018. Luettu 6.11.2019. https:// www.etk.fi/wp-content/uploads/Tilasto-suomenelakkeensaajista-2018.pdf

(11) Sosiaali- ja terveysministeriö. Kannustinloukut - Työkyvyttömyyseläkkeen ja ansiotulojen yhteensovittaminen sekä lineaarinen malli. necessary. More attention should be paid on the prevention of work disability of the unemployed, since that group is outside the benefits of occupational health services.

Keywords: : sickness absence, sickness allowance, sick leave, return to work, disability pension

$$
\begin{array}{cc}
\text { Saapunut } & 21.03 .2019 \\
\text { Hyväksytty } & 15.12 .2019
\end{array}
$$

Osatyökykyisille tie työelämään -kärkihanke (OTE). Sosiaali- ja terveysministeriön raportteja ja muistioita 2017:32.

(12) Karisalmi S, Gould R, Virta L. Työkyvyttömyyseläkeläiset eri järjestelmissä. Eläketurvakeskuksen raportteja 2009:2.

(13) Blomgren J, Hytti H, Gould R. Työkyvyttömyyseläkkeelle siirtyneiden työttömyys- ja sairaustausta eri eläkejärjestelmissä. Helsinki: Kela, Nettityöpapereita 26, 2011.

(14) Laaksonen M, Blomgren J, Gould R. Työkyvyttömyyseläkkeelle siirtyneiden sairauspäiväraha-, kuntoutus- ja työttömyyshistoria. Eläketurvakeskuksen raportteja 05/2014.

(15) Kivimäki M, Gimeno D, Ferrie J.E, ym. Socioeconomic position, psychosocial work environment and cerebrovascular disease among women: the Finnish public sector study. Int J Epidemiol 2009;38:1265-1271.

(16) Ervasti J, Joensuu M, Pentti J, ym. Prognostic factors for return to work after depressionrelated work disability: a systematic review and meta-analysis. J Psychiatr Res 2017;95:28-36.

(17) Ervasti, J., Vahtera, J., Pentti, J. ym. Return to work after depression-related absence by employees with and without other healthconditions: a cohort study. Psychosom Med 2015;77:126-135.

(18) Mattila-Holappa P, Ervasti J, Joensuu M, ym. Do predictors of return to work and recurrence of work disability due to mental disorders vary by age? A cohort study. Scand J Public Health 2017;45:178-184.

(19) Kausto J, Pentti J, Oksanen T, ym. Length of sickness absence and sustained return-to-work in mental disorders and musculoskeletal diseases: a cohort study of public sector employees. Scand J Work Environ Health 2017;43:358-366.

(20) Kausto J, Kaila-Kangas L, Leino-Arjas P, ym. Sairauspoissaolojen kesto, uusiutuminen ja onnistunut työhön paluu. Kuntatyöntekijöiden seurantatutkimus. Helsinki: Työterveyslaitos, 2018. 
(21) Viikari-Juntura E, Kausto J, Shiri R, ym. Return to work after early part-time sick leave due to musculoskeletal disorders: a randomized controlled trial. Scand J Work Environ Health 2012;38:134-143.

(22) Shiri R, Kausto J, Martimo K-P, ym. Healthrelated effects of early part-time sick leave due to musculoskeletal disorders: a randomized controlled trial. Scand J Work Environ Health 2013;39:37-45.

(23) Kausto J, Viikari-Juntura E, Virta LJ, ym. Effectiveness of new legislation on partial sickness benefit on work participation: a quasi-experiment in Finland. BMJ Open 2014;4:e006685.

(24) Viikari-Juntura E, Virta LJ, Kausto J, ym. Legislative change enabling use of early part-time sick leave enhanced return to work and work participation in Finland. Scand J Work Environ Health 2017;43:447-456.

(25) Halonen JI, Solovieva S, Pentti J, ym. Effectiveness of legislative changes obligating notification of prolonged sickness absence and assessment of remaining work ability on return to work and work participation: a natural experiment in Finland. Occup Environ Med 2016;73:42-50

(26) Halonen JI, Solovieva S, Virta LJ, ym. Sustained return to work and work participation after a new legislation obligating employers to notify prolonged sickness absence. Scand J Public Health 2018;46(Suppl 19):65-73.

(27) Pichler S. Sickness absence, moral hazard, and the business cycle. Health Econ 2015;24:692710 .

(28) Ervasti J, Vahtera J, Virtanen P, ym. Is temporary employment a risk factor for work disability due to depressive disorders and delayed return to work? The Finnish public sector study. Scand J Work Environ Health 2014;40:343-352.

(29) Reini K, Saarela J. Return to work after sickness absence: a register-based comparison of two indigenous population groups. Public Health 2019;169:93-100.

(30) Saari P. Työhön paluuseen liittyvät haasteet ja ratkaisukeinot pitkältä sairauslomalta. Kuntoutus 2013;1:32-38.

(31) Joensuu M, Lindström K. Työhön paluun ennustajat mielenterveyssyistä johtuvilta pitkiltä sairauslomilta. Työ ja ihminen 2009;21 (lisänumero 1):583-594.

(32) Laaksonen M, Blomgren J, Gould R. Sickness allowance trajectories preceding disability retirement: a register-based retrospective study. Eur J Public Health 2016;26:1050-1055.

(33) Laaksonen M, Blomgren J, Tuulio-Hendriksson A. Sickness allowance histories among disability retirees due to mental disorders: a retrospective case-control study. Scand J Public Health 2016;44:291-299.

(34) Salonen L, Blomgren J, Laaksonen M, ym. Sickness absence as a predictor of disability retirement in different occupational classes: a register-based study of a working-age cohort in Finland in 2007-2014. BMJ Open 2018;8:e20491.

(35) Kausto J, Virta L, Martimo K-P, ym. Myönteiset kokemukset rohkaisevat osasairauspäivärahan käyttöön. Suomen Lääkärilehti 2010;65:1719_ 1728.

(36) Kausto J, Virta L, Luukkonen R, ym. Associations between partial sickness benefit and disability pensions: initial findings of a Finnish nationwide register study. BMC Public Health 2010;10:361.

(37) Kausto J, Solovieva S, Virta LJ, ym. Partial sick leave associated with disability pension: propensity score approach in a register-based cohort study. BMJ Open 2012;2:e001752.

(38) Reho TTM, Atkins SA, Talola N, ym. Frequent attenders at risk of disability pension: a longitudinal study combining routine and register data. Scand J Public Health 2019; https:// doi.org/10.1177/1403494819838663.

(39) Blomgren J, Korpela T. Vähimmäismääräinen sairauspäiväraha ajaa usein myös toimeentulotuelle. Sosiaalivakuutus 2/2018. Luettu 9.8.2019. https://sosiaalivakuutus.fi/ vahimmaismaarainen-sairauspaivaraha-ajaausein-toimeentulotuelle/

(40) Perhoniemi R, Blomgren J, Laaksonen M. Mitä hylkäävän työkyvyttömyyseläkepäätöksen jälkeen? Työttömyys-, sairauspäivärahaja kuntoutusrahaetuudet sekä uudet eläkepäätökset neljän vuoden seurannassa. Yhteiskuntapolitiikka 2018;83:117-131.

(41) Perhoniemi R, Blomgren J, Laaksonen M. Sources of income following a rejected disability pension application: a sequence analysis study. Disabil Rehabil 2019;12:1-9.

(42) Nwaru CA, Kivimäki M, Pentti J, ym. Sickness absence in a re-employment program as a predictor of labour market attachment among long-term unemployed individuals: a 6-year cohort study in Finland. Scand J Work Environ Health 2018;44:496-502.

(43) Leinonen T, Solovieva S, Husgafvel-Pursiainen $\mathrm{K}$, ym. Do individual and work-related factors differentiate work participation trajectories before and after vocational rehabilitation? PLOS ONE 14:e0212498.

(44) Leinonen T, Viikari-Juntura E, HusgafvelPursiainen K, ym. The effectiveness of vocational rehabilitation on work participation: a propensity score matched analysis using nationwide register data. Scand J Work Environ Health 2019;45:651-660.
KAARINA REINI
FT, KTM, tutkija
Åbo Akademi Vaasa
Kasvatustieteiden ja byvinvointialojen tiedekunta Väestötieteen yksikkö 